Research Article

\title{
Curriculum Development Management In Increasing Student Excellence Research Context (Multisite Study at MTsN 1 Trenggalek and MTsN 2 Trenggalek)
}

\author{
M. Triono Al Fata ${ }^{1}$, Imam Fu'adi ${ }^{2}$, Ngainun Na'im ${ }^{3}$, Achmad Patoni $^{4}$, Maftukhin ${ }^{5}$, Akhyak $^{6}$ \\ ${ }^{1}$ STIT Sunan Giri Trenggalek, \\ 2,3,4,5,6 UIN Sayyid Ali Rahmatullah Tulungagung
}

\begin{abstract}
:
This research is motivated by the design of curriculum development management which has a strategic position in increasing student excellence. Improving student excellence is an opportunity for madrasas as educational institutions that can produce a generation of superior, capable, strong character, following the civilization of the times. Madrasas that have curriculum development designs by taking into account the strengths of students in accordance with their respective potential advantages will provide space and opportunities for students to strengthen their character and excellence. This research uses a qualitative approach with a field research design. The results of this study are, the design of curriculum development that is centered on knowledge, the design of curriculum development in madrasas consists of planning based on the foundation, principles, and goals of education with the vision, mission of the madrasa and programs to increase student excellence determined by the educational institution.
\end{abstract}

\section{Keywords: Management, Curriculum Development, Student Excellence}

\section{A. Preliminary}

The rationale for each student has its advantages, that every child born in this world has been chosen, selected, and excelled from hundreds of millions of sperm through an extraordinary process until he is born in the world. Children who are born into the world have their advantages that need to be directed and developed so that they grow into children who have advantages and good character.

Schools are educational laboratories that are very strategic to provide education and learning for students. Education and learning that is valuable and meaningful for students can grow and direct the excellence of students to be both focused and have a strong character. The advantages of students represented by various achievements, both academic and non-academic, will be more valuable and meaningful when they form the character of civilized students. This means that the advantages of students with their character are following the civilization of the times.

Education that gives birth to student excellence is not only related to the development of a good curriculum but the role of teachers in implementing knowledge transfer greatly affects the success of education. New research works have shown that, compared to the past, the education sector not only requires a higher level of education but also that it welcomes some new skills such as environmental management, problem-solving skills, creativity, etc. (Mostafa Ranai et al, 2012: 4568)

Management activities are very important to increase student excellence. Management is a process or framework that involves guiding or directing a group towards organizational goals or tangible goals (George R Terry and Leslie W Rue, 2015:1).

The management mindset in curriculum development is an interesting study and attention in its development in the world of education. Because the journey of education cannot be separated from the applied curriculum. And an effective, efficient, and quality curriculum is the hope that will bring enlightenment in improving the quality of education without burdening and giving excessive burdens to various parties.

Curriculum development design in increasing student excellence is a demand to facilitate the development of student excellence in madrasas or schools. So the design of curriculum development must pay attention to the needs of students and the needs of society in the future.

An effective curriculum is a curriculum that is developed with various alternatives and creativity, then implemented according to needs and in a relatively fast time. While efficient is the achievement of curriculum goals by using minimal resources but maximum results.

Curriculum development activities should be carried out with management knowledge because implementing curriculum development requires planning, supervision, including carrying out monitoring and evaluation activities. (Zainal Arifin, 2012:25). 


\section{Triono Al Fata et al / Curriculum Development Management In Increasing Student Excellence Research Context (Multisite Study at MTsN 1 Trenggalek and MTsN 2 Trenggalek)}

Curriculum development is essentially a process consisting of curriculum preparation, implementation, evaluation, and improvement to obtain a curriculum that is deemed ideal. (Sukiman, 2015:5-6). Curriculum development based on management means developing a curriculum using the concept of management or using the basic concept of management according to its function.

Curriculum development management needs to be designed as effectively and efficiently as possible to achieve the expected educational goals. In this case, it is related to efforts to increase student excellence. Effective and efficient curriculum development design while maintaining quality will accelerate the improvement of student excellence.

Curriculum development design needs to pay attention to local wisdom in line with research conducted by Ardiansyah, Suharno, and Triyanto (2018). The title "Implementation of cultural heritage through learning in elementary schools in the disruptive era of case studies in Surakarta City, carried out by researchers was promoted in two main forms, namely (1) through cultural heritage programs of habituation of daily life in learning, namely by applying the use of Javanese language as communication tools in the implementation of learning and singing folk songs; and (2) integrating cultural heritage materials in subjects such as arts including Javanese dance, or as extracurricular activities in the form of Karawitan Arts. Javanese language and cultural heritage are the focus of this research (Ardiansyah, et.al. 2018: 48-53).

Curriculum development by integrating local wisdom will be relevant to the needs of the community. So that educational institutions that pay attention to local wisdom in the content and implementation of their curriculum will be relevant to the goals of education.

\section{B. Theoretical Review}

Experts' opinions about curriculum development are seen as a product of development after a curriculum evaluation is held for further changes for the better. In its development, the curriculum covers a wide area. Curriculum development has a comprehensive meaning consisting of planning, implementation, and evaluation because curriculum development indicates changes and progress. (Syafaruddin and Amiruddin, 2017:131)

Anim Nurhayati (2010) quoting from A. Glatthorn (1987) defines curriculum as plans made to guide learning in schools usually include documents, general levels, and actualization of those plans in class, as student experiences have been recorded. and written by an expert, these experiences are placed in a learning environment that also influences what is learned.

Meanwhile, according to Law Number 20 of 2003 concerning the National Education System, the curriculum is a set of plans and arrangements regarding the objectives, content, and learning materials as well as the methods used as guidelines for the implementation of learning activities to achieve certain educational goals. From the various understandings of the curriculum both in language, terms, and curriculum meanings based on experts, curriculum management can be interpreted as a process or system of managing curriculum in a cooperative, comprehensive, and systematic way to refer to the achievement of curriculum objectives that have been formulated.

In education management, Dadang Supardan, (2009) curriculum implementation aims so that the curriculum can be implemented properly. In this case, the management is tasked with providing material, personal, and conditions facilities so that the curriculum can be implemented continuously.

\section{The implementation of the curriculum is divided into two, namely:}

1. Implementation of the school-level curriculum, which in this case is directly handled by the principal. In addition to being responsible so that the curriculum can be implemented in schools, the principal is also obliged to carry out activities, namely compiling an academic calendar that will take place at the school for one year, compiling a lesson schedule in one week, setting the duties and obligations of teachers, and other related matters. about efforts to achieve curriculum goals.

2. Implementation of the class-level curriculum, which in this case is divided and assigned directly to the teachers. This division of tasks includes:

A. Activities in the field of teaching and learning process.

B. Fostering extracurricular activities that are outside the curriculum provisions to support school goals.

C. Tutoring activities aim to develop the potential that is in students and help students in solving problems.

A must in the curriculum, starting from the goals expected by the curriculum itself to the form of arrangement to carry out the measurement process for the activities carried out. In every curriculum, there must be at least three elements, namely content, skills, and assessment. (Ali Rahimi et al, 2010: 2071)

Lidia Susanti in the introduction to her book said that achievement is the ability to solve difficult things, master, excel, compete, and exceed other students to face and resolve obstacles and meet high standards or levels. The advantages of students represented by learning achievements are also the basis for success in the learning process or individual abilities in carrying out learning by the standards they meet. (Lidia Susanti, 2019)

According to researchers, student excellence is an achievement that must be maintained and developed. Not only is it a symbol of achievement but it also really has advantages that are beneficial for oneself and others. Therefore, the management of curriculum 


\section{Triono Al Fata et al / Curriculum Development Management In Increasing Student Excellence Research Context (Multisite Study at MTsN 1 Trenggalek and MTsN 2 Trenggalek)}

development that leads to increased student excellence needs to be designed in such a way that the advantages and benefits of students can be felt.

This study will discuss how the management of curriculum development in improving student excellence. The discussion in this paper is focused on the design of curriculum development in increasing student excellence. Discussion on the theoreticalconceptual domain of the development of thinking and experience in the field in implementing curriculum development in increasing student excellence.

\section{Research Methods}

The research approach used is qualitative with a descriptive method. Research is conducted on natural objects, natural objects are objects that develop as they are. Not manipulated by researchers and the presence of researchers is not so dynamic on the object. In qualitative research, the instrument is the researcher himself. The data analysis carried out is inductive based on the facts found in the field and then constructed into a hypothesis or theory. Qualitative methods are used to obtain in-depth data, data that contains meaning. Meaning is actual data, definite data which is a value behind visible data. Sugiono (2017).

The type of research taken by the researcher is the type of field research (field research), where the research results are based on the results from the field, Lexy J. Moleong. (2012). Field research is essentially a method to find out specifically and realistically what is happening at a time in the community. This study aims to solve practical problems in everyday life, Aji Damanuri (2010).

\section{Results and Discussion}

\section{Curriculum Development Design in Improving Student Excellence}

Design is related to the design, pattern, or model. Designing curriculum development means developing a curriculum development design or model following the school's mission and vision. The duties and roles of a curriculum development designer determine the materials and methods of developing a new curriculum following the conditions of the educational environment.

The development of the quality of educational institutions cannot be separated from curriculum management. Curriculum development is effective only if it involves the participation of teachers in the learning process. In other words, the efficiency of the curriculum as the core of learning development is not only determined by the curriculum package but the participation and cooperation of the teachers. (Ali Rahimi et al., 2010: 2070)

Curriculum management that is carried out sustainably will be able to follow the development of needs in the community. The education system has undergone various developments and changes, namely curriculum problems. Thus the selection and organization of curriculum content, implementation, and evaluation of the curriculum, development, distribution, and use of teaching materials, as well as the relevance of the curriculum are urgently needed at this time. Teachers are the most influential factor in educational change. (Ashish Kumar Parashar and Rinku Parashar, 2012: 686)

The curriculum development design that has been running so far uses the knowledge-centered design and The cores design.

1. The knowledge-centered design. The design pattern of knowledge-centered curriculum development is designed based on the structure of disciplines, therefore this design model is also called the academic subject curriculum model whose emphasis is directed to the intellectual development of students.

2. The core design. According to this concept, the cores of teaching materials are centered on individual and social needs. The core design is also known as the core curriculum.

The design of curriculum development at MTsN 1 Trenggalek and MTsN 2 Trenggalek in principle has planning and organization that is regulated and systematic in the rules from the government for madrasas to develop according to needs. The development model is theoretically the same as the Hilda Taba curriculum development model whose curriculum development steps are explained (Sukiman, 2013: 100) that:

a) Determining the purpose of Education, with the Steps:

(1) Formulate general goals

(2) Classifying goals

(3) Detailing goals in the form of knowledge (facts, ideas, concepts), thinking, values and attitudes, emotions and feelings, skills.

(4) Formulate goals in a specific form.

b) Identify and select learning experiences, with the following steps:

(1) Identify student interests and needs

(2) Identify and adapt to social needs

(3) Determine the breadth and depth of learning

(4) Determining the balance between scope and depth 
M. Triono Al Fata et al / Curriculum Development Management In Increasing Student Excellence Research Context (Multisite Study at MTsN 1 Trenggalek and MTsN 2 Trenggalek)

c) Organizing curriculum materials and learning activities

(1) Determine curriculum organization

(2) Determine the order or sequence of curriculum materials

(3) Perform curriculum integration

(4) Determine the focus of the lesson

d) Evaluating the results of curriculum implementation

(1) Determining the assessment criteria

(2) Develop a comprehensive evaluation program

(3) Data collection technique

(4) Interpretation of evaluation data

(5) Translating evaluations into the curriculum.

The curriculum development design includes plans which include; the basis, principles, and objectives that have been set out in Permendikbud number 35 of 2018 concerning Amendments to the Regulation of the Minister of Education and Culture number 58 of 2014 concerning the 2013 Curriculum for Junior High Schools / Madrasah Tsanawiyah. So that formal educational institutions in implementing the curriculum refer to the rules and regulations that are set to apply to be used as guidelines and references in carrying out educational activities. Likewise at MTsN 1 Trenggalek and MTsN 2 Trenggalek in curriculum development 2013 referring to the Minister of Education and Culture Regulation.

Planning for curriculum development in educational institutions needs to choose a strategy, especially in the learning area because it is important so that the learning process in the classroom can run properly. This is because of the complexity of the procedures and steps in learning. There are three stages to achieve learning outcomes, one of which is interviewing students, teachers, and alumni. In addition, questionnaires were used to improve the teaching and learning environment. However, this approach ignores student learning behavior which will provide better insight into curriculum assessment according to curriculum guidelines (Satrio Adi Priyambada et al, 2017: 265)

The urgency of the curriculum development foundation has a very important role. If the curriculum is likened to a building, then a strong building is a building that has a strong foundation or foundation, as well as the structure of the building. The foundation or foundation is not strong, it will easily collapse when hit by the wind or a shock occurs. Likewise with the curriculum, if it does not have a strong foundation or foundation, the curriculum will be difficult to focus on, easily swayed and the victims will be students who are produced by education that does not have a strong foundation or foundation in curriculum development.

The foundations for curriculum development at MTsN 1 Trenggalek and MTsN 2 Trenggalek use foundations that are tailored to the needs that are relevant to the times, namely:

\section{First; Philosophical foundation, Curriculum 2013 was developed using the following philosophy:}

The basic framework that is used as a reference in the basis for developing the 2013 Curriculum at MTsN 1 Trenggalek and MTsN 2 Trenggalek is very relevant to the values of Pancasila philosophy which are reflected in the goals of national education contained in Law No. 20 of 2003 concerning the National Education System which functions to develop abilities and shape character and a dignified national civilization to educate the nation's life, aims to develop the potential of students to become human beings who believe and are devoted to God Almighty, have a noble character, are healthy, knowledgeable, capable, creative, independent and become democratic and responsible citizens.

\section{Second, the Sociological Foundation}

Curriculum development at MTsN 1 Trenggalek and MTsN 2 Trenggalek uses a sociological basis because the 2013 curriculum was developed based on the need for changes in educational design and processes to meet the dynamics of community, nation, and state life, as stated in the national education goals. Today the development of education in Indonesia cannot be separated from the development of science, technology, and art. This change is possible due to the development of new demands in society, the world of work, and the world of science which have implications for the demands for continuous curriculum changes. It is intended that education can always answer the demands of change by the times. Thus the output of education will be able to contribute optimally to build a knowledge-based society. (Copy of Attachment 1 to the Regulation of the Minister of Education and Culture Number 35 of 2018).

\section{Third, the Psychopedagogical Foundation}

Using a psycho-pedagogical foundation in the development of the 2013 curriculum at MTsN 1 Trenggalek and MTsN 2 Trenggalek because as it refers to Permendikbud number 35 of 2013 that the 2013 curriculum is intended to meet the demands of the realization of the conception of education that is centered on the development of students and their life contexts as interpreted in the transformative pedagogy concept. This conception demands that the curriculum must be positioned as a vehicle for the 


\section{Triono Al Fata et al / Curriculum Development Management In Increasing Student Excellence Research Context (Multisite Study at MTsN 1 Trenggalek and MTsN 2 Trenggalek)}

maturation of students following their psychological development and receive pedagogical treatment by the environmental context and era. This need is especially a priority in designing curriculum for secondary education, especially SMP/MTs. Therefore, the implementation of education in SMP/MTs, which so far has put more emphasis on knowledge, needs to be developed into a curriculum that emphasizes the process of building attitudes, knowledge, and skills of students through various approaches that are intellectual and educational. Mastery of subject matter is no longer emphasized on understanding sterile concepts from people's lives but building knowledge through authentic learning. Thus the curriculum and learning in addition to reflecting the content of knowledge as part of human civilization also realize the process of cultivating students throughout life. Psycho Pedagogical foundations at MTsN 1 Trenggalek and MTsN 2 Trenggalek also have spiritual values that are integrated with the process of education and teaching activities.

\section{Fourth, Theoretical Foundation}

As referred to Permendikbud number 35 of 2018 MTsN 1 Trenggalek and MTsN 2 Trenggalek use a theoretical basis because the 2013 Curriculum was developed on the theory of "standard-based education" and competency-based curriculum theory. Education-based standards stipulate the existence of national standards as the minimum quality of citizens which are detailed into content standards, process standards, graduate competency standards, educators and education personnel standards, facilities and infrastructure standards, management standards, financing standards, and educational assessment standards. The competencybased curriculum is designed to provide the widest possible learning experience for students in developing the ability to behave, be knowledgeable, skilled, and act.

\section{Fifth, Juridical Foundation}

The government and the state are always present to oversee the improvement of the quality of education through regulations and laws that are made in such a way. The juridical foundation of the 2013 Curriculum at MTsN 1 Trenggalek and MTsN 2 Trenggalek cannot be separated from the applicable laws and regulations.

The philosophical, psycho-pedagogical, sociological, theoretical, and juridical foundations in the development of the 2013 curriculum are very valuable and meaningful in realizing the curriculum. Awareness is increasing student excellence that is relevant to the development of the times and still pays attention to the philosophical, psycho-pedagogical, sociological, theoretical, and juridical values that have been determined. Do not let the realization of the curriculum in its development be far from the guided base.

The foundation of curriculum development has a very strategic position in overseeing curriculum development. Therefore, awareness of the foundation of curriculum development must exist in every educational institution in Indonesia. So that the increase in learning achievement is realized and born from awareness, not coercion of a policy.

The principles of curriculum development have a very strategic position in controlling the movement of curriculum development. Because in the process of developing a curriculum that follows the times, it must still not be out of the principles of curriculum development that have been determined. Being aware of holding the principles of curriculum development makes curriculum development well-controlled and well-controlled. The principles of curriculum development at MTsN 1 Trenggalek and MTsN 2 Trenggalek pay attention to several things, namely the principle of relevance, the principle of effectiveness, the principle of efficiency, continuity, flexibility, and the principle of being goal-oriented.

The urgency of the principles of curriculum development is to control and protect curriculum development from negative influences, and to bring the direction of curriculum development by the expectations and goals of national education.

The purpose of curriculum development must always be presented in curriculum development processes because goals are important to present the direction of curriculum development that can be known and understood in curriculum development processes. The objectives of curriculum development that are presented by educational institutions will help oversee the direction of curriculum development so that it is following the goals set. The formulation of curriculum development goals at MTsN 1 Trenggalek and MTsN 2 Trenggalek consists of institutional and instructional objectives.

Institutional goals The curriculum of MTsN 1 Trenggalek and MTsN 2 Trenggalek is a tool to realize the vision and mission of educational institutions. More specifically, the purpose of curriculum development is to achieve the vision, namely as an educational center that can realize the vision and mission that has been set.

While the instructional objectives, in this case, include Core Competencies (KI) and Basic Competencies (KD). Referring to the Regulation of the Minister of Education and Culture of the Republic of Indonesia Number 35 of 2018 concerning Amendments to the Regulation of the Minister of Education and Culture Number 58 of 2014 concerning the 2013 Curriculum for Junior High Schools / Madrasah Tsanawiyah.

Core Competence is the level of ability to achieve Graduate Competency Standards (SKL) which must be possessed by a student at every grade level. Core competencies are designed for each class. Through core competencies, horizontal synchronization of various basic competencies between subjects in the same class can be maintained. In addition, vertical synchronization of various basic competencies in the same subjects in different classes can also be maintained. The formulation of core competencies uses the following notation:

a. Core Competency-1 (KI-1) for the core competence of spiritual attitudes; 


\section{Triono Al Fata et al / Curriculum Development Management In Increasing Student Excellence Research Context (Multisite Study at MTsN 1 Trenggalek and MTsN 2 Trenggalek)}

b. Core Competency-2 (KI-2) for the core competence of social attitudes;

c. Core Competency-3 (KI-3) for knowledge core competencies; and

d. Core Competency-4 (KI-4) for core competency skills.

Then Basic Competencies are formulated to achieve Core Competencies. The formulation of Basic Competencies is developed by taking into account the characteristics and abilities of students, and the peculiarities of each subject. Basic Competencies include four groups by the grouping of Core Competencies as follows:

a. Group 1: Basic Competence group for spiritual attitudes to describe KI-1;

b. Group 2: Basic Competence of social attitudes to describe KI-2;

c. Group 3: Basic Knowledge Competence group to describe KI-3; and

d. Group 4: Basic Skills Competency group to describe KI-4.

Therefore, to achieve the success of students in meeting various standards of competence, teachers need to have success criteria related to the teaching and learning process. This is an indicator of mastery learning. If the student in studying certain material has met the specified success criteria, then the student is considered to have succeeded in understanding the material that has been taught by the teacher. A parallel curriculum was established in Austria forty years ago but not anymore because someone made a week plan or a day plan, which is completely different. And kids know exactly what to do today or this week and can start working at their own pace without wasting time. (E.K. Hyry-Beihammer, T. Hascher, 2015: 110)

\section{E. Conclusion}

Curriculum development design at MTsN 1 Trenggalek and MTsN 2 Trenggalek in increasing student excellence uses the knowledge-centered curriculum development design pattern and the core design, namely the knowledge-centered curriculum development design.

Knowledge-centered is a curriculum development design pattern that is structured or designed based on the structure of disciplines. Therefore, a design model like this is called a curriculum development model for academic subjects which emphasizes the direction of the intellectual development of students. While the core of teaching materials that are centered on individual needs and social needs is the concept of the core design or commonly called the core curriculum.

The combination of curriculum development from the Ralph Tyler model and the Hilda Taba model. On the one hand, it is deductive (Tyler's model), because for educational purposes it refers to the National Education Goals. However, when viewed from the other side, it can be inductive (Taba Model). And the design of curriculum development in madras as consists of plans based on the foundation, principles, and goals of education with the vision, mission of the madrasa, and programs to increase student excellence determined by the educational institution itself.

\section{F. Reference}

1. Aji Damanuri, Metodologi Penelitian Mu'amalah, Ponorogo, STAIN Ponorogo Press, 2010

2. Ali Rahimi et al. / Curriculum mapping: a strategy for effective participation of faculty members in curriculum development, International Journal on Procedia Social and Behavioral Sciences 9 (2010) 2069-2073

3. Anim Nurhayati, Inovasi Kurikulum; Telaah terhadap Pengembangan Kurikulum Pendidikan Pesantren, Yogyakarta: Teras, 2010,

4. Ardiansyah, et al. / Inheritance National Culture Through Learning in Elementary School at Disruptive Era: Case Study in Surakarta Indonesia. International Journal of Educational Research Review 3 (2018): 48-53.

5. Arifin. Zainal, 2012. Konsep dan Model Pengembangan Kurikulum, Bandung: Remaja Rosdakarya, 2012.

6. Ashish Kumar Parashar and Rinku Parashar / Innovations and Curriculum Development for Engineering Education and Research in India, International Journal on Procedia - Social and Behavioral Sciences 56 ( 2012 ) 685 - 690

7. Belgin Tanrıverdi and Özlem Apak / Pre-service Teachers' Beliefs about Curriculum Orientations, International Journal on Procedia - Social and Behavioral Sciences 116 ( 2014 ) $842-848$

8. Dadang Supardan dkk, Manajemen Pendidikan, Bandung; Alfabeta, 2009,

9. E.K. Hyry-Beihammer, T. Hascher / Multi-grade teaching practices in Austrian and Finnish primary schools, International Journal of Educational Research 74 (2015) 104-113

10. Fadlillah, M.2014. Implementasi Kurikulum 2013 dalam Pembelajaran SD/MI, SMP/MTs \& SMA/MA, Yogyakarta: Ar-Ruzz Media.

11. George R Terry dan Leslie W Rue. 2015. Dasar- dasar Manajemen Terjemah, G.A Ticolu, Jakarta: Bumi Aksara.

12. Imas Kurniasih dan Berlin Sani, 2014. Sukses Mengimplementasikan Kurikulum 2013 Memahami Berbagai Aspek dalam Kurikulum 2013, Jakarta: Kata Pena.

13. Lexy J. Moleong, Metodologi Penelitian Kualitatif Bandung, PT Remaja RosdaKarya, 2012

14. Mostafa Ranai et al. / Challenges rooted in curriculum globalization, International Journal on Procedia - Social and Behavioral Sciences 46 (2012 ) 4567 - 4570 
M. Triono Al Fata et al / Curriculum Development Management In Increasing Student Excellence Research Context (Multisite Study at MTsN 1 Trenggalek and MTsN 2 Trenggalek)

15. Salinan Lampiran 1 Peraturan Menteri Pendidikan dan Kebudayaan Nomor 35 tahun 2018

16. Satrio Adi Priyambada et al. / Curriculum Assessment of Higher Educational Institution Using Aggregate Profile Clustering, International Journal on Procedia Computer Science 124 (2017) 264-273

17. Sugiono, Metodologi Penelitian Pendidikan Pendekatan Kuantitatif, Kualitatif, dan R\&D, Bandung: Alfabeta, 2017

18. Sukiman, 2013. Pengembangan Kurikulum, Teori dan Praktik Pada Perguruan Tinggi, Yogyakarta: Fakultas Tarbiyah dan Keguruan UIN Yogyakarta, 2013.

19. Sukiman, 2015. Pengembangan Kurikulum, Bandung: Rosda Karya.

20. Susanti, Lidia. 2019, Prestasi Belajar Akademik \& Non Akademik Teori dan Implementasinya, Malang: Literasi Nusantara.

21. Syafaruddin dan Amiruddin, 2017. Manajemen Kurikulum, Medan: Perdana Publishing, 2017.

22. UU Nomor 20 Tahun 2003 Tentang Sistem Pendidikan Nasional, Surabaya, PT Nasional. 